\title{
KAJIAN TEKNO EKONOMI UNIT ALAT PENCACAH PLASTIK UNTUK MENINGKATKAN NILAI JUAL SAMPAH PLASTIK: STUDI KASUS-UD. SARI PLASTIK LOMBOK TIMUR, NTB
}

Techno Economic Studies of Plastic Shredder Units to Increase The Sale Value of Plastic Waste: Case Study-UD. Sari Plastik East Lombok, NTB

\author{
I Made Suartika ${ }^{1}$, Made Wijana $^{2}$, Muhamad Sudrajadinata ${ }^{3}$ \\ 1,2,3 Jurusan Teknik Mesin Fakultas Teknik Universitas Mataram \\ JIn. Majapahit No.62 Mataram Nusa Tenggara Barat Kode Pos: 83125, Telp. (0370) 636087; \\ 636126; ext. 128, Fax (0370) 636087
}

\begin{abstract}
Processing plastic waste in East Lombok mostly just collect plastic waste processing and then sent to the city in its original form. If the plastic waste is processed by applying plastic shredded units or chopper machine technology, the sale value of the plastic waste will be increased. This study describes to determine of feasibility technical and economic aspects to apply the plastic shredder units. The method used in this study is quantitative method in which the author will be a number of data collection is needed in relation to the issues to be examined, so that the research results can be trusted and relied upon the truth.

The results of the study found that the engine performance in terms of the efficiency of each stage of the production process of shredded plastic. To purchase process stages, sorting, drying, packaging, and selling obtained an efficiency of 0.938, while the efficiency of the shredding process is 0.906 . Furthermore, to obtain a production capacity of $1230.01 \mathrm{~kg} /$ day processing owners must buy raw materials $1588.34 \mathrm{~kg} /$ day by the number of machines required 2 units of 3 units of existing plastic shredder. So based on the feasibility analysis in terms of the value of BEP, obtained at 29092.03 kilogram production capacity, with a total cost of $R p$ 176,424,168.75, NPV Rp 113,545,038.34 (>0) and Net B/C ratio of 1.79 (>0) otherwise feasible. By optimizing the engine to 3 units obtained BEP value equal to the NPV Rp 385.139.485,25 $(>0)$ and Net $B / C$ ratio of $4.01(>0)$. From the analysis of the value of shredded plastic BEP selling price is higher than the selling price of plastic intact from $R p 3,531 / \mathrm{kg}$ into $R p$ $6.064,35 / \mathrm{kg}$.
\end{abstract}

Keywords: Waste Plastics, Plastic shredder unit, BEP, NPV, Net B/C Ratio.

\section{PENDAHULUAN}

Sampah yang tidak dikelola dengan baik, akan menimbulkan berbagai masalah kehidupan bagi sumbernya, seperti bau busuk, pemandangan yang tidak sedap, adanya potensi berkembangnya sarang penyakit, terutama yang disebarkan oleh lalat, tikus dan serangga, sehingga berdampak pada sanitasi lingkungan yang buruk dan kelestarian alam. Namun sebaliknya bila mampu dikelola dengan baik akan memberikan dampak positif dalam bidang sanitasi dan ekonomi [1].

Pengelolaan sampah merupakan suatu tindakan penanganan sampah (Municipal Waste Management-MWM) mulai dari penimbunan, penyimpanan setempat, pengangkutan, pemerosesan sampai pembuangan akhir, dengan menggunakan prinsip kesehatan masyarakat, ekonomi, teknik keindahan perlindungan alam [1], [2].

Kondisi pengelolaan sampah di Kabupaten Lombok Timur masih menerapkan sistem penanganan langsung yang bersumber dari masyarakat yang dibuang ke tong sampah dan selanjutnya diambil oleh petugas untuk diangkut ke tempat pembuangan akhir (TPA) di ljo Balit [3]. Untuk pengusaha kecil hanya terbatas pada penyediaan sampah plastik saja, artinya sampah plastik yang sudah terkumpul dijual dalam bentuk utuh (tanpa dicacah terlebih dahulu) ke bandar pengolahan. Apabila sampah dicacah terlebih dahulu maka harganya akan menjadi lebih mahal bila dibandingkan dengan sampah utuh. Untuk memperoleh pendapatan yang lebih besar diperlukan alat pencacah sampah plastik sehingga pengusaha kecil (pemulung atau masyarakat pegiat sampah) dapat termotivasi dalam kegiatan pengurangan sampah dari sumbernya yang sering disebut dengan 3R (Reuse, Reduce, dan Recycle) [4].

Salah satu teknologi yang digunakan dalam pengolahan sampah plastik adalah mesin pencacah plastik [5], akan tetapi 
teknologi pengolahan sampah plastik akan menimbulkan beberapa pembiayaan diantaranya adalah biaya investasi, biaya operasional, serta biaya perawatan yang bertujuan agar mesin pencacahnya dapat dipergunakan secara terus menerus.

Berdasarkan hal tersebut diatas, maka diperlukan studi kelayakan pemanfaatan mesin pencacah plastik dalam proses pengolahan sampah plastik untuk meningkatkan nilai jual sampah plastik.

\section{DASAR TEORI \\ Sampah Plastik}

Pemanfaatan limbah plastik merupakan salah satu upaya untuk menekan pembuangan plastik seminimal mungkin [6]. Selain itu, dalam batas tertentu menghemat sumber daya dan mengurangi ketergantungan akan bahan baku impor. Pemanfaatan limbah plastik dapat dilakukan dengan pemakaian kembali (reuse) maupun daur ulang (recycle) [7].

Berdasarkan sifat fisiknya, plastik dapat digolongkan berdasarkan [6] :

1. Termoplastik, merupakan jenis plastik yang bisa didaur-ulang/dicetak lagi dengan proses pemanasan ulang. Contohnya seperti polietilena (PE), polistiren (PS), ABS, polikarbonat (PC).

2. Termoset, merupakan jenis plastik yang tidak bisa didaur-ulang/dicetak lagi. Pemanasan ulang akan menyebabkan kerusakan molekul-molekulnya. Contoh: resin epoksi, bakelit, resin, melamin, ureaformaldehida [8].

\section{Pengolahan Sampah Plastik}

Penanganan sampah plastik meliputi kegiatan-kegiatan sebagai berikut:

\section{Pengumpulan Sampah Plastik}

Pengumpulan sampah plastik dilakukan dengan melibatkan beberapa lembaga informal yaitu pemulung, lapak, dan bandar. Pelaku daur ulang sampah plastik biasanya mengumpulkan sampah plastik untuk selanjutnya diperjual belikan hingga berakhir pada industri daur ulang sampah plastik.

\section{Pemilahan Sampah Plastik}

Pemilahan sampah plastik yang dilakukan saat ini masih dilakukan oleh pelaku daur ulang yang pertama, yaitu pemulung/perangkas. Pemulung/perangkas biasanya mulai memilah sampah menurut jenisnya langsung di tempat sampah atau di TPS (Tempat Penampungan Sementara).

\section{Kompaksi}

Aktivitas selanjutnya setelah dipilah berdasarkan jenisnya adalah aktivitas kompaksi. Proses yang dilakukan disini adalah memipihkan botol-botol plastik menjadi tipis.

\section{Fabrikasi}

Aktivitas akhir yang dilakukan adalah fabrikasi, yaitu proses mengubah sampah plastik menjadi bijih plastik (recycle), dengan menggunakan metode melting dan peletisasi. Aktivitas fabrikasi biasanya dilakukan pada tingkat industri recycle, karena teknologi yang digunakan membutuhkan modal yang cukup besar.

Tekno Ekonomi Unit Alat Pencacah Plastik

Tekno-ekonomi adalah suatu teknik analisis dalam mengambil suatu keputusan dari berbagai alternatif rancangan teknis atau rencana investasi yang dianggap sama-sama memenuhi syarat.

\section{METODE PENELITIAN}

Penelitian ini menggunakan metode kuantitatif dimana penulis akan melakukan pengumpulan data berupa angka yang dibutuhkan sehubungan dengan masalah yang akan diteliti, sehingga hasil penelitiannya dapat lebih dipercaya dan diandalkan kebenarannya. Disamping itu juga penelitian ini juga menggunakan studi literatur untuk mendapatkan teori, data-data serta gambar yang diperlukan.

\section{A. Lokasi Penelitian}

Penelitian ini dilakukan di UD. Sari Plastik Lombok Timur milik $H$. Sirajudin, Dusun Nensing, Desa Rarang Tengah, Kecamatan Terara, Kabupaten Lombok Timur.

\section{B. Pengumpulan Data}

Data-data yang dikumpulkan adalah data teknis, komponen biaya-biaya pengolahan sampah plastik berupa biaya investasi, biaya operasional, biaya perawatan dan pendapatan dari penjualan sampah plastik.

\section{Analisa Data dan Pembahasan}

Dalam menganalisa data dilakukan pengkajian berdasarkan aspek teknis dan ekonomisnya.

1. Kaji Teknik

Dalam kaji teknik yang dianalisis mengenai sistem pengolahan sampah plastik yang diterapkan di lokasi penelitian. Analisis ini meliputi analisis unit alat pencacah plastik, kapasitas produksi, tata letak dan proses poduksi.

Pada analisa kapasitas produksi menggunakan rumus [9]: 
$\mathrm{N}=\frac{\mathrm{T}}{60} \frac{\mathrm{P}}{\mathrm{D} \times \mathrm{E}}$

Dimana:

$\mathrm{P}=$ Jumlah produk yang harus dibuat oleh masing-masing mesin per periode waktu kerja (unit produk/tahun)

$\mathrm{T}=$ Total waktu pengerjaan yang dibutuhkan untuk proses operasi produksi yang diperoleh dari hasil time study atau perhitungan secara teoritas (menit/unit produk).

$\mathrm{D}$ = Jumlah operasi mesin yang tersedia.

$E=$ Faktor efisiensi mesin yang disebabkan oleh adanya setup,break down, repair atau hal-hal lain yang menyebabkan terjadinya idle.

$\mathrm{N}=$ Jumlah mesin atau operator yang dibutuhkan untuk operasi produksi.

2. Kaji Ekonomi

Kreteria yang digunakan dalam evaluasi kelayakan investasi pengolahan sampah plastik adalah [10]:

a. Break Event Point (BEP)

$$
B E P(X)=\frac{F C}{p-c}
$$

Dimana:

$$
\begin{array}{ll}
\text { BEP }(\mathrm{X})= & \text { Titik Impas } \\
\mathrm{FC} & =\text { Biaya Tetap } \\
\mathrm{P} & =\text { Pendapatan yang diterima } \\
& \text { perkilogram } \\
\mathrm{C} & =\text { Biaya variabel perkilogram }
\end{array}
$$

b. Net Present Vaiue (NPV) [11]

$$
N P V=\sum_{\mathrm{t}=0}^{\mathrm{n}} \frac{B_{t}-C_{t}}{(1+i)^{t}}
$$

Dimana:

$$
\begin{aligned}
\mathrm{Bt}= & \begin{array}{c}
\text { Penerimaan yang diperoleh pada } \\
\text { tahun ke-t }
\end{array} \\
\mathrm{Ct}= & \begin{array}{l}
\text { Biaya yang dikeluarkan pada } \\
\text { tahun ke-t }
\end{array} \\
\mathrm{n}= & \text { Umur ekonomis proyek } \\
\mathrm{i} \quad= & \text { Tingkat suku bunga }(\%) \\
\mathrm{t}= & \text { Tahun investasi }(\mathrm{t}=0,1,2 \ldots . . \mathrm{n})
\end{aligned}
$$

c. Net Benefit Cost Ratio (Net B/C Ratio) [11]

$$
\operatorname{Net} \frac{B}{C}=\frac{\sum_{t=0}^{n} \frac{B_{t}-C_{t}}{(1+i)^{t}}>0}{\sum_{t=0}^{n} \frac{B_{t}-C_{t}}{(1+i)^{t}}<0}
$$

Dimana:

$\mathrm{Bt}=$ Penerimaan yang diperoleh pada tahun ke-t

$$
\begin{aligned}
\mathrm{Ct} & =\text { Biaya yang dikeluarkan pada tahun } \\
& \text { ke-t } \\
\mathrm{n} & =\text { Umur ekonomis proyek } \\
\mathrm{i} & =\text { Tingkat suku bunga }(\%) \\
\mathrm{t} & =\text { Tahun investasi }(\mathrm{t}=0,1,2 \ldots . . \mathrm{n})
\end{aligned}
$$

\section{HASIL DAN PEMBAHASAN \\ Kajian Teknik}

Mesin pencacah plastik merupakan mesin yang digunakan untuk menghancurkan plastik menjadi ukuran yang lebih kecil.

Dalam penelitian ini mesin pencacah plastik yang digunakan di Dusun Nensing Desa Rarang Tengah Kecamatan Terara ada tiga kapasitas:

1. Kapasitas 700 Kilogram perhari.

Mesin cacah plastik kapasitas 700

Kilogram perhari merupakan mesin yang mampu mencacah plastik dengan raatarata 700 kilogram perdelapan jam kerja dalam sehari. Motor penggerak yang digunakan adalah jenis Mitsubisi dengan daya 28 PK dan jumlah pisau pencacah adalah tujuh.

2. Kapasitas 1.000 Kilogram perhari.

Mesin cacah plastik kapasitas 1.000 Kilogram perhari merupakan mesin yang mampu mencacah plastik dengan raatarata 1.000 kilogram perdelapan jam kerja dalam sehari. Motor penggerak yang digunakan adalah jenis Yanmar dengan daya $30 \mathrm{PK}$ dan jumlah pisau pencacah adalah tujuh.

3. Kapasitas 1.500 kilogram perhari.

Mesin cacah plastik kapasitas 1.500 Kilogram perhari merupakan mesin yang mampu mencacah plastik dengan raatarata 1.500 kilogram perdelapan jam kerja dalam sehari. Motor penggerak yang digunakan adalah jenis Xinfong dengan daya $36 \mathrm{PK}$ dan jumlah pisau pencacah adalah tujuh.

Komponen-komponen utama pada mesin pencacah plastik adalah komponenkomponen mesin yang didapatkan pada saat penelitian antara lain:
a. Motor penggerak
b. Poros
c. Pulley
d. Sabuk (Belt)
e. Pisau pencacah
f. Penyaring plastik

\section{Analisa Kapasitas Produksi Pengolahan Cacahan Plastik}

Berdasarkan penelitian yang dilakuan didapat rata-rata masukan bahan baku plastik adalah $48.417,92 \mathrm{~kg} / \mathrm{bulan}$ dan rata-rata hasil 
cacahan yang diperoleh adalah $36.900,33$ $\mathrm{kg} / \mathrm{bulan}$

Di dalam sebuah produksi cacahan plastik terdiri dari beberapa tahapan utama, tahapan utama proses produksi cacahan plastik dapat dilihat pada tabel 1 .

Tabel 1. Tabel tahapan utama produksi cacahan plastik

\begin{tabular}{clcccc}
\hline Proses & Aktivitas & (Jam/hari) & (Men/kg) & (Men/hari) & $\%(p)$ \\
\hline 1 & Pembelian & 8 & 0,297 & 30 & - \\
\hline 2 & Pemilahan & 8 & 0,338 & 30 & 12 \\
\hline 3 & Pencacahan & 8 & 0,390 & 45 & 12 \\
\hline 4 & Pengeringan & 8 & 0,390 & 30 & - \\
\hline 5 & Pengemasan & 8 & 0,390 & 30 & - \\
\hline 6 & Penjualan & 8 & 0,390 & 30 & - \\
\hline
\end{tabular}

Dari Tabel 1 dapat ditentukan:

1. Efisiensi dari masing-masing tahapan proses dengan menggunakan rumus umum [9]:

2.

$$
E=1-\frac{\text { Waktu yang terbuang per periode }}{\text { Jam operasi kerja per periode }}
$$

a. Untuk tahap prose ke 1.

$$
\begin{aligned}
E_{1} & =1 \frac{30 \text { Menit/Hari }}{60 \times 8 \text { Menit/Hari }} \\
& =0,94
\end{aligned}
$$

b. Untuk tahap proses proses ke 2, 4, 5, 6 sama dengan tahap proses ke 1.

c. Untuk tahap proses ke 3.

$$
\begin{aligned}
E_{3} & =1 \frac{45 \text { Menit/Hari }}{60 \times 8 \text { Menit/Hari }} \\
& =0,91
\end{aligned}
$$

3. Jumlah produk dari masing-masing tahapan proses

Untuk menentukan jumlah produk dari masing-masing tahapan proses dilakukan cara perhitungan terbalik, yaitu dari tahap proses terakhir menuju ketahap proses awalnya. Rumus umum untuk menghitung ini adalah [9]:

$$
\mathrm{Pi}=\frac{\mathrm{P}_{\mathrm{g}, \mathrm{i}}}{1 \mathrm{p} ;} ; \mathrm{i}=1,2, \ldots, \mathrm{n}
$$

$P_{g, 6}=36.900,33 \mathrm{Kg} /$ Bulan $=1.230,01 \mathrm{~kg} /$ hari
a. Untuk tahap proses ke 6

$$
P_{6}=\frac{1.230,011}{1}=1.230,01 \mathrm{~kg} / \mathrm{hari}
$$

b. Untuk tahap proses ke 5 dan 4 sama dengan tahap proses ke 6

c. Untuk tahap proses ke 3

$$
P_{3}=\frac{1.230,011}{1-12 \%}=1.397,74 \mathrm{~kg} / \mathrm{hari}
$$

d. Untuk tahap proses ke 2

$$
P_{2}=\frac{1.397,74}{1-12 \%}=1.588,34 \mathrm{~kg} / \text { hari }
$$

e. Untuk tahap proses ke 1 sama dengan tahap proses ke 2 .

4. Jumlah mesin yang dibutuhkan untuk tahapan pencacahan.

Untuk menentukan jumlah mesin dari tahap proses pencacahan dipergunakan rumus [9]:

$$
\begin{gathered}
N=\frac{T}{60} \times \frac{P}{D \times E} \\
N=\frac{0,390}{60} \times \frac{1.397,74}{8 \times 0,906}=1,254=2
\end{gathered}
$$

Jumlah mesin yang dibutuhkan adalah 2 unit. Artinya dari bahan baku 48.417,92 $\mathrm{kg} / \mathrm{bulan}$ cukup hanya menggunakan 2 unit mesin dari 3 mesin yang ada.

\section{Tata Letak Pabrik}

Tata letak adalah suatu landasan utama dalam dunia industri. Tata letak pabrik (Plant layout) atau tata letak fasilitas (Fasilities layout) dapat didefinisikaan sebagai tata cara pengaturan fasilitas-fasilitas pabrik guna menunjang kelancaran proses produksi. Gambar 1 menunjukkan stasiun kerja pengolahan cacahan plastik. 


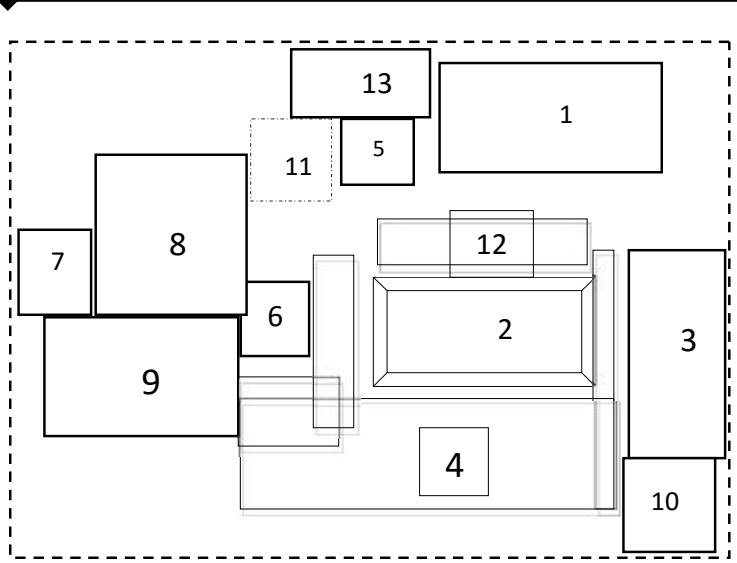

Gambar 1 Stasiun kerja pengolahan cacahan plastik.

Keterangan gambar:

No1,2,3 : Rumah pemilik

No 4 : Tempat pemilahan bahan baku plastik dengan luas $156 \mathrm{~m}^{2}$

No 5,6,7 : Luas area yang diperuntukkan untuk meletakkan mesin

No 8,9,10 : Tempat untuk mengeringkan hasil cacahan plastik

No 11,12 : Tempat untuk menyimpan hasil cacahan plastik

No 13 : Area yang diperuntukkan untuk pembuangan limbah dengan luas $35 \mathrm{~m}^{2}$

Luas area keseluruhan stasiun kerja adalah $1.000 \mathrm{~m}^{2}$.

\section{Proses Produksi Cacahan Plastik}

Proses produksi cacahan plastik melalui beberapa tahapan yaitu:

1. Proses pembelian bahan baku.

Bahan baku plastik didapat dari tiga sumber yaitu pengepul, pengampas dan pemulung yang berada di pulau Lombok. Harga beli bahan baku plastik dapat dilihat pada tabel 2 .

Tabel 2. Harga beli bahan baku plastik

\begin{tabular}{cll}
\hline No & Bahan baku plastik & $\begin{array}{c}\text { Harga } \\
(\mathrm{Rp} / \mathrm{Kg})\end{array}$ \\
\hline 1 & Plastik & 2.500 \\
\hline 2 & Botol bening (PET I) & 4.000 \\
\hline 3 & Botol warna (PET II) & 3.500 \\
\hline 4 & Gelas bening (Natula) & 6.300 \\
\hline 5 & Gelas warna (PP warna) & 3.000 \\
\hline 6 & Oli & 3.700 \\
\hline 7 & Yakult & 2.500 \\
\hline 8 & Botol campuran & 3.000 \\
\hline 9 & Tutup Botol & 3.000 \\
\hline
\end{tabular}

Rata-rata pembelian bahan baku perbulannya adalah $48.417,917 \mathrm{~kg}$.

2. Proses pemilahan

Pemilahan bahan baku plastik bertujuan untuk memisahkan plastik sesuai dengan jenis masing-masing plastik.

3. Proses pencacahan

Rata-rata hasil cacahan yang diperoleh oleh pemilik modal dalam satu bulan adalah $36.900,333 \mathrm{~kg}$.

4. Proses pengeringan

Lama dari proses pengeringan tergantung dari cuaca, apabila cuaca cerah (panas) maka cacahan plastik bisa kering dalam waktu setengah hari.

5. Proses pengemasan

6. Proses penyimpanan

Cacahan plastik yang sudah dikemas kemudian disimpan pada satu tempat supaya ketika proses penjualan, cacahan bisa dijual dalam jumlah banyak.

7. Proses penjualan/pengiriman

Penjualan cacahan plastik dilakukan 2 kali dalam satu bulan ke PT. Sari Plastik di Pasuruan Sidoarjo.

\section{Kajian Ekonomi}

Analisisa Biaya Pengolahan Cacahan Plastik

\section{Biaya Tetap}

Biaya tetap dalam pengolahan cacahan plastik terdiri dari biaya penyusutan mesin pencacah, sewa tanah dan biaya peralatan kerja. Nilai penyusutan tersebut dihitung dengan menggunakan metode garis lurus (straight line method). Jumlah biaya tetap yang dikeluarkan oleh pemilik pengolahan cacahan plastik tiap tahunnya adalah $\mathrm{Rp}$ 16.008.600.

\section{Biaya Tidak Tetap}

Biaya tidak tetap adalah biaya yang dikeluarkan oleh pemilik pengolahan cacahan plastik selama proses pengolahan berlangsung. Biaya ini terdiri dari biaya operasional dan biaya perawatan. 


\section{a. Biaya Operasional}

Tabel 3. Biaya operasional bulanan pengolahan cacahan plastik

\begin{tabular}{lll}
\hline Komponen Biaya & Jumlah & Harga (Rp) \\
\hline a. Bahan baku plastik & $48.417,92 \mathrm{Kg}$ & $170.963 .783,33$ \\
\hline b. Tenaga kerja langsung & 15 orang & 17.100 .000 \\
\hline c. BBM & $180 \mathrm{Liter}$ & 990.000 \\
\hline d. Oli & $28 \mathrm{Liter}$ & 812.000 \\
\hline e. Air & $283,5 \mathrm{~m}^{3}$ & 127.575 \\
\hline f. Tali rapia & $12 \mathrm{rol}$ & 96.000 \\
\hline g. Karung plastik & $1.211 \mathrm{biji}$ & 3.633 .000 \\
\hline h. Transportasi & - & 3.000 .000 \\
\hline i. Ongkos kirim & - & 5.400 .000 \\
\hline Jumlah biaya operasional & & $202.122 .358,33$ \\
\hline
\end{tabular}

\section{b. Biaya Perawatan (Maintenance)}

Besarnya rata-rata biaya perawatan (maintenance) yang dikeluarkan oleh pemilik mesin dalam satu bulan adalah $\mathrm{Rp}$ 1.348.750

Total biaya tidak tetap bulanan adalah Rp 203.471.108,33.

\section{Analisa Pendapatan Pengolahan Cacahan Plastik}

\section{Kapasitas Produksi Cacahan Plastik} dan Pendapatan Kotor

Dari hasil penelitian yang dilakukan diketahui rata-rata kapasitas cacahan plastik yang diperoleh perbulannya dari bahan baku plastik 48.417,92 kilogram mengalami penyusutan $24 \%$, sehingga kapasitas hasil cacahannya adalah 36.900,33 kilogram. Dengan rata-rata harga jual $\mathrm{Rp}$ 223.776.416,67 atau Rp 6.064,35/kilogram

\section{Analisis Break Even Point (BEP) Pengolahan Cacahan Plastik}

Berdasarkan data biaya yang telah didapatkan dan pendapatan yang telah diketahui dalam penggunaan mesin pencacah plastik, selanjutnya akan digunakan sebagai data untuk menganalisa nilai Break Even Point.

Dimana:

$$
\mathrm{x}=\frac{\mathrm{FC}}{\mathrm{p}-\mathrm{c}}
$$

Harga jual plastik cacahan $(p)=$

Total pendapatan

Kapasitas cacahan
$=\frac{\operatorname{Rp} 223 \cdot 776 \cdot 416,67}{36 \cdot 900,33}$

$$
=\operatorname{Rp} 6.064,35 / \mathrm{kg}
$$

Biaya tetap $(\mathrm{FC}) \quad=\mathrm{Rp} 16.008 .600$

Variabel Cost untuk $1 \mathrm{~kg}$ cacahan plastik (c)

$$
\begin{aligned}
& =\frac{V C}{\text { Kapasitas cacahan }}=\frac{\operatorname{Rp} 203 \cdot 471 \cdot 108,33}{36.900,33} \\
& =\operatorname{Rp} 5.514,07 / \mathrm{kg}
\end{aligned}
$$

Sehingga jumlah cacahan plastik yang dijual perbulan untuk mencapai titik impas adalah:

$$
\mathrm{x}=\frac{\mathrm{FC}}{\mathrm{p}-\mathrm{c}}
$$

$$
\text { Rp 16.008.600 }
$$

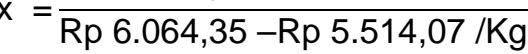

$$
\begin{aligned}
& x=29.092,03 \text { kilogram }
\end{aligned}
$$

Total biaya produksi perbulan untuk mencapai titik impas adalah:

$\mathrm{TC}=$ Jumlah biaya tetap + Biaya produksi

Dimana

$\mathrm{VC}=\mathrm{cX}$

$=\operatorname{Rp} 5.514,072 \times 29.092,03 \mathrm{~kg}$

$=\operatorname{Rp~160.415.568,75}$

$\mathrm{TC}=\mathrm{FC}+\mathrm{VC}$

$=\operatorname{Rp~16.008.600+Rp~160.415.568,75~}$

$=\operatorname{Rp} 176.424 .168,75$

Dengan cara grafik nilai BEP dapat dilihat seperti pada gambar 2 . 


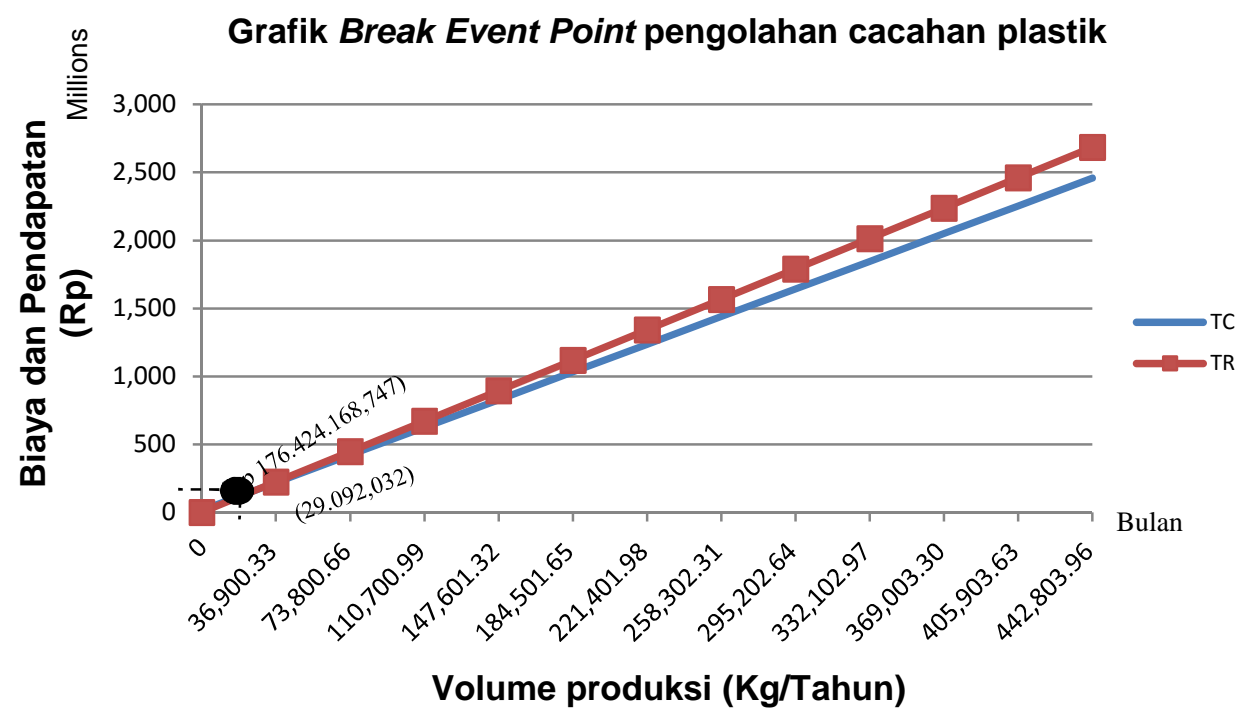

Gambar 2. Grafik Break Event Point pengolahan cacahan plastik

\section{Analisis Net Present Value (NPV) Pengolahan Cacahan Plastik}

Berdasarkan data biaya yang telah didapatkan, selanjutnya akan digunakan sebagai data untuk menganalisa apakah usaha tersebut layak atau tidak layak ditinjau dari analisis Net Present Value (NPV) menggunakan persamaan,

$$
N P V=\sum_{\mathrm{t}=0}^{\mathrm{n}} \frac{B_{t}-C_{t}}{(1+i)^{t}}
$$

Dari hasil perhitungan didapat NPV pengolahan cacahan plastik dengan umur investasi 10 tahun sebesar $\mathrm{Rp}$ $113.545 .038,34(>0)$.

Analisa Net Benefit Cost Ratio (Net B/C Ratio) Pengolahan Cacahan Plastik

Net Benefit Cost Ratio (Net B/C Ratio) digunakan untuk menunjukkan gambaran berapa kali lipat manfaat (benefit) yang diperoleh dari biaya biaya (cost) yang dikeluarkan.

$$
\begin{aligned}
\text { Net } \frac{B}{C}=\frac{\sum_{t=0}^{n} \frac{B_{t}-C_{t}}{(1+i)^{t}}>0}{\sum_{t=0}^{n} \frac{B_{t}-C_{t}}{(1+i)^{t}}<0} \\
\text { Net } \frac{B}{\mathrm{C}}=\frac{257.255 .863,285}{143.710 .824,950} \\
=1,79
\end{aligned}
$$

Dari hasil perhitungan diatas Net B/C penggunaan mesin pencacah plastik dengan umur investasi 10 tahun adalah 1,79. Artinya dari Rp 1 biaya yang dikeluarkan mampu menghasilkan manfaat bersih sebesar $\mathrm{Rp}$ 1,79 .

Kajian Ekonomi Pengolahan Cacahan Plastik Dengan Kapasitas Maksimal Mesin 1. Biaya Tetap
Biaya tetap yang dikeluarkan pemilik pengolahan cacahan plastik disini sama dengan biaya tetap sebelumnya.

\section{Biaya Tidak Tetap}

Besarnya rata-rata biaya tidak tetap yang dikeluarkan tiap bulannya oleh pemilik pengolahan cacahan plastik dengan kapasitas maksimal mesin adalah Rp 403.429.716,62

Analisa Pendapatan Pengolahan Cacahan Plastik Dengan Kapasitas Maksimal Mesin Kapasitas cacahan plastik perbulan

$$
=\text { Kapasitas mesin }- \text { Penyusutan }
$$$$
=96.000-\text { Penyusutan } 24 \%
$$$$
=73.163,66 \text { Kilogram }
$$

Harga jual cacahan plastik

$=$ Rata-rata harga jual per kilogram $\mathrm{x}$ kapasitas cacahan plastik perbulan

$=\operatorname{Rp~6.064,35\times 73.163,66}$

$=\operatorname{Rp~443.689.804,91.~}$

\section{Analisa Break Event Poin Pengolahan}

Cacahan Plastik Dengan Kapasitas Maksimal Mesin

Di bawah ini dapat dilihat nilai Break Event Point penggunaan mesin pencacah plastik berdasarkan kapasitas maksimal mesin.

Dimana:

$$
\mathrm{x}=\frac{\mathrm{FC}}{\mathrm{p}-\mathrm{c}}
$$

Harga jual plastik cacahan ( $p$ )

$$
\begin{aligned}
(\mathrm{p}) & =\frac{\text { Total pendapatan }}{\text { Kapasitas cacahan maksiml mesin }} \\
& =\frac{\operatorname{Rp~443.689.804,91}}{73.163,66} \\
& =\operatorname{Rp~} 6.064,35 / \mathrm{Kg}
\end{aligned}
$$

Biaya tetap (FC)

$\mathrm{FC}=\mathrm{Rp} 16.008 .600$

Variabel Cost untuk $1 \mathrm{~kg}$ cacahan plastik (c) 


$$
\begin{aligned}
& \mathrm{C}=\frac{\mathrm{VC}}{\text { Kapasitas cacahan maksimal }} \\
& =\frac{\operatorname{Rp~403\cdot 429\cdot 716,62}}{73 \cdot 63,66} \\
& =\operatorname{Rp~5.514,07/\mathrm {kg}}
\end{aligned}
$$

Jumlah cacahan plastik yang dijual perbulan untuk mencapai titik impas $(x)$ adalah:

$$
\begin{aligned}
& \mathrm{X}=\frac{\mathrm{FC}}{\mathrm{p}-\mathrm{c}} \\
& \mathrm{X}=\frac{\mathrm{Rp} 16.008 .600}{\mathrm{Rp} 6.064,35-\mathrm{Rp} 5.514,07 / \mathrm{Kg}} \\
& \mathrm{X}=29.092,03 \text { kilogram } \\
& \text { Total biaya produksi perbulan untuk } \\
& \text { pai titik impas adalah: } \\
& \text { TC = Jumlah biaya tetap + Biaya }
\end{aligned}
$$
mencapai titik impas adalah: Dimana;

$$
\begin{aligned}
\mathrm{VC} & =\mathrm{cx} \\
& =\operatorname{Rp} 5.514,07 \times 29.092,03 \mathrm{Kg} \\
& =\operatorname{Rp} 160.415 .568,75 \\
\mathrm{TC}= & \mathrm{FC}+\mathrm{VC} \\
= & \operatorname{Rp} 16.008 .600+\mathrm{Rp} \\
& 160.415 .569,75 \\
= & \operatorname{Rp} 176.424 .168,75
\end{aligned}
$$

\section{Perbandingan Kapasitas Produksi 48.417,92 kg/bulan Dengan Kapasitas Produksi Maksimal Mesin $\quad(96.000$ $\mathrm{kg} /$ bulan)}

Perbandingan antara kapasitas produksi 48.417,92 kg dengan kapasitas produksi maksimal mesin $(96.000 \mathrm{~kg}$ dapat dilihat pada gambar

3.

Grafik perbandingan kapasitas produksi $48.417,92$ $\mathrm{Kg} /$ Bulan dengan kapasitas produksi maksimal mesin

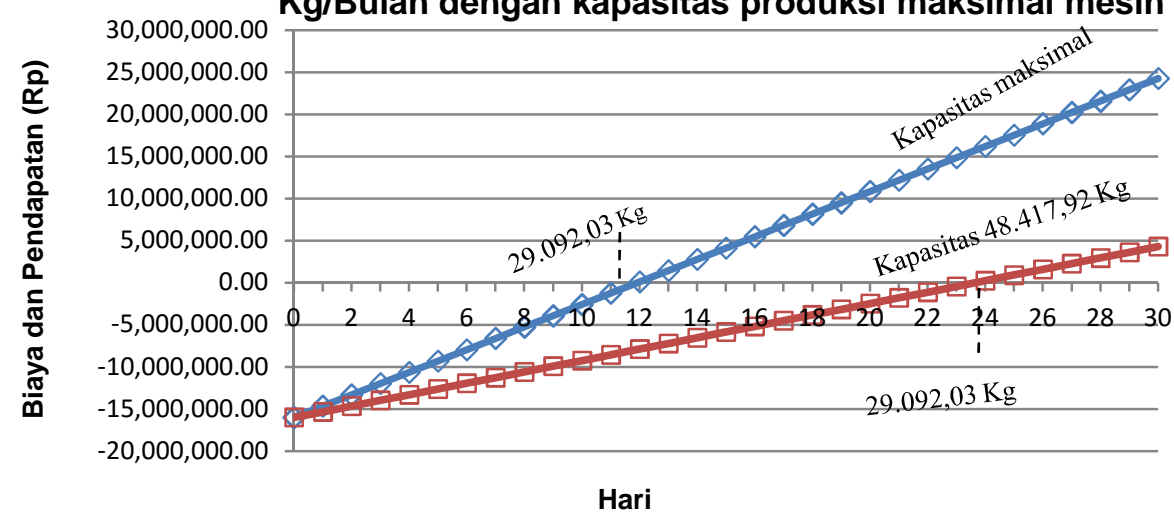

Gambar 3. Grafik perbandingan kapasitas produksi 48.417,92 kg/bulan dengan kapasitas produksi maksimal mesin $(96.000 \mathrm{~kg} / \mathrm{bulan})$.

Berdasarkan grafik pada gambar 3, diketahui pada saat kapasitas produksi 0 atau hari ke 0 , pemilik pengolahan cacahan plastik mengalami kerugian sebesar Rp. 16.008.600. Pada hari ke 12 kebawah penggunaan mesin pencacah kapasitas produksi 48.417,92 kilogram maupun kapasitas produksi maksimal mesin tidak layak disebabkan pemilik pengolahan masih mengalami kerugian. Pada hari ke 12 sampai hari ke 24 penggunaan mesin pencacah kapasitas produksi kapasitas maksimal layak, penggunaan mesin pencacah kapasitas produksi 48.417,92 kilogram tidak layak, disebabkan karena pada kapasitas produksi maksimal mesin sudah mendapatkan keuntungan sedangkan pada kapasitas produksi 48.417,92 kilogram masih mengalami kerugian. Pada hari ke 24 keatas penggunaan mesin pencacah kapasitas produksi 48.417,92 kilogram layak dan untuk kapasitas produksi maksimal mesin jauh lebih layak, disebabkan keuntungan yang didapat pada kapasitas produksi maksimal mesin lebih besar dibandingkan kapasitas produksi 48.417,92 kilogram.

\section{KESIMPULAN}

Dari hasil analisa data dan pembahasan, maka dapat diambil kesimpulan sebagai berikut :

1. Performansi mesin pencacah ditinjau dari: a. Efisiensi

Efisiensi tahapan proses pembelian, pemilahan, pengeringan, pengemasan, dan penjualan adalah 0,938 sedangkan efisiensi proses pencacahan adalah 0,906. b. Kapasitas produksi

Untuk memenuhi rata-rata kapasitas produksi 36.900,33 kg/bulan atau 1.230,01 $\mathrm{kg}$ /hari, dibutuhkan bahan baku $1.588,34$ kg/hari.

c. Jumlah mesin atau operator

Jumlah mesin yang ada (existing) adalah 3 unit dengan kapasitas 700, 1.000 , dan $1.500 \mathrm{~kg} /$ hari dengan bahan 
baku plastik 48.417,92 kilogram/bulan. Hasil analisa data dengan kapasitas bahan baku yang tersedia dibutuhkan mesin pencacah $1,254 \approx 2$ unit.

2. Kelayakan pemanfaatan alat pencacah plastik ditinjau dari:

a. Break event point (BEP)

Nilai break event point sistem produksi dengan kapasitas bahan baku plastik 48.417,92 kilogram/bulan dan kapasitas maksimal mesin (96.000 kilogram/bulan) adalah sama yaitu pada kapasitas produksi 29.092,03 kilogram, dengan total biaya pengeluaran (TC) adalah $\mathrm{Rp}$ 176.424.168,75. Tetapi waktu untuk mencapai titik impas/nilai BEP adalah berbeda. Kapasitas bahan baku 48.417,92 kilogram BEP pada hari ke 24, sedangkan kapasitas maksimal mesin BEP pada hari ke 12.

Berdasarkan nilai BEP yang didapat, rata-rata harga jual plastik cacahan lebih tinggi (meningkat) dibandingkan rata-rata harga jual plastik utuh yaitu dari $\mathrm{Rp} 3.531$ per kilogram menjadi Rp 6.064,35 per kilogram atau meningkat dua kali lipat/200\%.

b. Net present value (NPV)

Dengan umur investasi 10 tahun pendapatan bersih (NPV) yang diperoleh dengan kapasitas bahan baku plastik 48.417,92 kilogram/bulan adalah $\mathrm{Rp}$ 113.545.038,34 (>0), sedangkan dengan kapasitas maksimal mesin $(96.000$ kilogram/bulan) pendapatan bersih yang diperoleh adalah $\mathrm{Rp} 385.139 .485,25$ (>0). Artinya secara finansial usaha pencacahan plastik tersebut layak dilaksanakan.

c. Net benefit cost rasio (Net B/C)

Perbandingan antara jumlah Present Value positif dengan Present Value negatif (Net $B / C$ Ratio) pada kapasitas bahan baku plastik 48.417,917 kilogram/bulan adalah 1,79 (>1), sedangkan dengan kapasitas maksimal mesin (96.000 kilogram/bulan) diperoleh Net B/C Ratio 4,10 (>1). Artinya secara finansial usaha pencacahan plastik layak dilaksanakan.

Berdasarkan ketiga kriteria analisa kelayakan dapat disimpulkan bahwa kapasitas produksi maksimal mesin (96.000 kilogram/bulan) lebih layak dibandingkan kapasitas produksi 48.417,92 kilogram/bulan, karena keuntungan yang diperoleh lebih besar. Sehingga untuk mengoptimalkan nilai BEP atau keuntungan dari pengolahan cacahan plastik dapat dilakukan dengan cara menambah bahan baku, mengoptimalkan mesin, jam kerja tenaga kerja, dan mengatur stasiun kerja dalam kontek optimalisasi mesin existing.

\section{DAFTAR PUSTAKA}

[1] Marshall, R.E., Farahbakhsh, K., 2013, Systems Approaches to Integrated Solid Waste management in Developing Countries,. Journal Waste Management. Elsevier 33 (2013) 9881003.

(www.elsivier.com/locate/wasman Januari 2015).

[2] Sudjana, I.M.P., 2011, Pengolahan Sampah, GaneC Swara, Vol 5, No 1, p. 58.

[3] Kantor Kebersihan dan Tata Kota Lombok Timur. 2014. Laporan Hasil Survey Tinjuan Lapangan Lombok Timur. NTB.

[4] Zurbrugg C., Gfrerer M., Ashadi H., Brenner W., Kuper D., 2012,. Determinants of Sustainability in Solid Waste Management-The Gianyar Waste Recovery Project in Indonesia,. Journal Waste Management. Elsevier. 32: 2126-2133.

(www.elsevier.com/locate/wasmanJanuari 2015).

[5] Hartono, S., 1986, Sampah dan Penanggulangannya, Buletin Kesehatan. Direktoral Jendral PUM, Depkes RI Jakarta.

[6] Zheng,Y., dan Yanful, E.K., 2005,. A Review of Plastic Waste Biodegradation. Critical Reviews in Biotechnology, 25:243-250. (http://id.wikipedia.org/wiki/plastik).

[7] Anonim, 2009, Pengolahan Limbah Plastik Dengan Metode Daur Ulang (Recycle),

http://onlinebuku.com/2009/01/20/peng olahan-limbah-plastik dengan-metodedaur-ulang-recycle/ (Rabu, 16 Oktober 2013).

[8] Ahvenainen, R., 2003, Modern Plastics Handbook (edisi ke-1). Woodhead Publishing Limited.

[9] Wignjosoebroto, S., 2000, Tata Letak Pabrik dan Pemindahan Barang, Edisi 3, Guna Widya Surabaya.

[10] Pujawan,I.N., 1995, Ekonomi Teknik, Guna Widya, Surabaya.

[11] Gittinger., 1986, Analisa Ekonomi Proyek- Proyek Pertanian, Edisi Kedua, UIPress, Jakarta. 